\title{
Assessment of antiproliferative, cytotoxic and proapoptotic properties of selected flavonoids in relation to liver cancers - in vitro studies
}

\author{
Ocena właściwości przeciwproliferacyjnych, cytotoksycznych \\ i proapoptotycznych wybranych flawonoidów w stosunku do nowotworów \\ wątroby w badaniach in vitro \\ Tomasz Skalny, Anna Kleczka (D), Robert Kubina (D), Aleksandra Owczarzy, Magdalena Wyszyńska (D), \\ Agata Kabała-Dzik \\ Department of Pathology, Faculty of Pharmaceutical Sciences in Sosnowiec, \\ Medical University of Silesia in Katowice, Poland
}

\begin{abstract}
INTRODUCTION: Flavonoids belong to phytotherapeutics with a wide spectrum of pharmacological activity. It has been proven that flavonoids possess properties that can inhibit the development of cancer by inducing cells into the programmed cell death process. The aim of the work was to demonstrate the apoptotic, antiproliferative and cytotoxic properties of selected flavonoids.

MATERIAL AND METHODS: The test material was the human primary hepatocellular carcinoma SK Hep-1 cell line. The tested compounds were assessed for cytotoxicity with the MTT assay. The next step was to evaluate the level of protein expression from the Bcl-2 family using the human Bcl-2 ELISA test.

RESULTS: The compound with the strongest cytotoxic properties confirmed by the MTT test is chrysin, the $\mathrm{IC}_{50}$ value of which was $316.67 \mu \mathrm{M} / \mathrm{L}$. In the case of all the tested compounds, apoptotic processes were confirmed by the human Bcl-2 ELISA test. The highest level of Bcl-2 protein expression occurred after 48 hours after the administration of chrysin, hesperidin, naringin and kaempferol.

CONCLUSIONS: On the basis of the obtained research results, it can be concluded that the studied flavonoids (chrysin, hesperidin, naringin, kaempferol) exhibit cytotoxic, proapoptotic and antiproliferative properties in relation to SK Hep-1 hepatoma cells.
\end{abstract}

\section{KEY WORDS}

apoptosis, Bcl-2, naringin, hesperidin, MTT, chrysin, SK Hep-1, kaempferol

\section{Received: 16.10 .2019 \\ Revised: 30.10 .2019 \\ Accepted: 31.12 .2019 \\ Published online: 27.11 .2020}

Address for correspondence: Dr hab. n. med. Agata Kabała-Dzik, Katedra i Zakład Patologii, Wydział Nauk Farmaceutycznych w Sosnowcu, Śląski Uniwersytet Medyczny w Katowicach, ul. Ostrogórska 30, 41-200 Sosnowiec, Polska, tel. +48 32364 13 54, e-mail: adzik@sum.edu.pl

Copyright @ Śląski Uniwersytet Medyczny w Katowicach

www.annales.sum.edu.pl 


\section{STRESZCZENIE}

WSTĘP: Flawonoidy należą do fitoterapeutyków o szerokim spektrum działania farmakologicznego. Udowodniono, że flawonoidy posiadają właściwości mogące hamować rozwój choroby nowotworowej poprzez wywoływanie w komórkach procesu programowanej śmierci komórki. Celem pracy było wykazanie właściwości apoptotycznych, antyproliferacyjnych oraz cytotoksycznych wybranych flawonoidów.

MATERIAŁ I METODY: Materiał do badań stanowiła ludzka linia komórkowa pierwotnego raka wątrobowokomórkowego. Badane związki poddano ocenie cytotoksyczności za pomocą testu MTT. Kolejnym etapem była ocena poziomu ekspresji białek z rodziny Bcl-2 testem Human Bcl-2.

WYNIKI: Związkiem posiadającym najsilniejsze właściwości cytotoksyczne, potwierdzone testem MTT, jest chryzyna, której wartość IC50 wyniosła 316,67 $\mu \mathrm{M} / \mathrm{L}$. W przypadku wszystkich badanych związków stwierdzono zainicjowanie procesów apoptotycznych potwierdzone testem Human Bcl-2 ELISA. Najwyższy poziom ekspresji białek Bcl-2 miał miejsce po upływie 48 godzin od podania chryzyny, hesperydyny, narynginy i kemferolu.

WNIOSKI: Na podstawie uzyskanych wyników badań można wnioskować, że badane flawonoidy (chryzyna, hesperydyna, naryngina, kemferol) wykazują właściwości cytotoksyczne, proapoptotyczne i antyproliferacyjne w stosunku do komórek raka wątrobowokomórkowego SK Hep-1.

\section{SŁOWA KLUCZOWE \\ apoptoza, BCL-2, chryzyna, hesperydyna, naryngina, MTT, SK Hep-1, kemferol}

\section{INTRODUCTION}

The greatest problem of developed and developing countries is civilization diseases, which include hypertension, diabetes, and cancer. According to WHO data, 14 million new cancer cases were registered in 2012, and it is forecast that over the next two decades the incidence of cancer will increase by about $70 \%$ [1].

Liver cancer ranks fifth in terms of the incidence of cancer worldwide and ranks third among the causes of death in cancer patients [2]. Only in 2014, almost 2,000 patients died in Poland due to liver cancer [3]. In recent years, there has been a worrying increase in the mortality in liver cancer patients in Europe and North America. While global statistics showed that the number of oncological deaths has decreased recently, the mortality from liver cancer has increased by $2.4 \%$ every year [4]. The poor prognosis of patients with liver cancer is due to the problematic early diagnosis and limited therapeutic options. The method of patient treatment is determined not only by the type and size of the neoplastic lesion, but also by liver function and the general condition of the patient [5].

The latest research indicates that therapy using natural components is becoming more widely used in cancer patients. Plant preparations have a proven analgesic efficacy; they can be used as agents that inhibit cancer wasting and reduce the side effects of chemotherapy [6].

Flavonoids are commonly used in the therapy and prevention of many diseases. Knowing the huge possibilities and widespread occurrence, these relationships have become a very frequent object of research for numerous research institutes. Numerous meta-analyses confirm the significant influence of the flavonoid molecule structure on not only antioxidant but also anticancer, anti-neurodegenerative, cardioprotective, antipyretic, anti-diabetic, and anti-bacterial properties [7].
Numerous studies have confirmed that flavonoids can regulate the process of apoptosis in a cell at various stages. They affect cyclin-dependent kinases (CDKs), caspases, Bcl-2 family proteins, the epidermal growth factor (EGF), serine/threonine kinase (AKT), mitogen activated kinases (MAPK), and the NF- $\kappa$ B transcription factor. It should also be mentioned that the induction of apoptosis did not occur in healthy cells, but only in those with cancer, which additionally speaks in favor of this group of compounds $[8,9]$.

Anticancer activity has been demonstrated, among others for flavonoids, which, among others, inhibit the formation of free radicals, have an antioxidant effect, and limit the development of inflammation [10].

Phenolic compounds are widespread in nature. To date, over 8000 different flavones have been described, which due to their chemical structure are divided into 7 subgroups. Chrysin, a compound found in honey and propolis, protects animal tissues against viral and bacterial infections, prevents osteoporosis, reduces blood pressure, and prevents diabetes. Its antiproliferative effect has been demonstrated on breast cancer cells $[11,12]$. Studies have also shown that chrysin can suppress the human immunodeficiency virus (HIV).

Hesperidin obtained mainly from citrus fruits also has antiproliferative and cytotoxic properties against cancer cells. Studies to date have already shown the toxic effects of hesperidin on breast, ovarian, prostate, colorectal and leukemia cells $[13,14,15]$. In addition, this compound, due to its antioxidant and anti-inflammatory properties, may be used in the chemoprevention of tumors [16].

Naringin is a compound found in citrus fruits and grapes. It has very strong antioxidant and anti-inflammatory properties. Enriching the diet with naringin reduces the risk of obesity, diabetes, and hypertension [17]. The possibility of using naringin in oncological therapy is being investigated because of its beneficial effect on the metabolism of chemotherapy drugs. 
Kaempferol, which is present in tea, apples, strawberries, and broccoli, can affect the apoptosis, angiogenesis, and proliferation of cancer cells. It also modulates the inflammatory process [18]. Studies have shown that taking kaempferol reduces the risk of prostate and colorectal cancer and also increases the activity of caspases in existing cancer [19].<smiles>O=c1cc(-c2ccccc2)oc2cc(O)cc(O)c12</smiles><smiles>CC1OC2C(O)C(O)C(O)C2OC(Oc2cc(O)c3c(c2)O[C@@H](c2ccc(O)cc2)CC3=O)C(OCCO)C(O)C(O)C1O</smiles>

tion. The SK-Hep1 cell line was cultured according to the manufacturer's instructions.

\section{Human adenocarcinoma SK Hep-1 cell culture}

The SK Hep-1 liver primary tumor cell line was provided from the ECACC (European Collection of Authen-
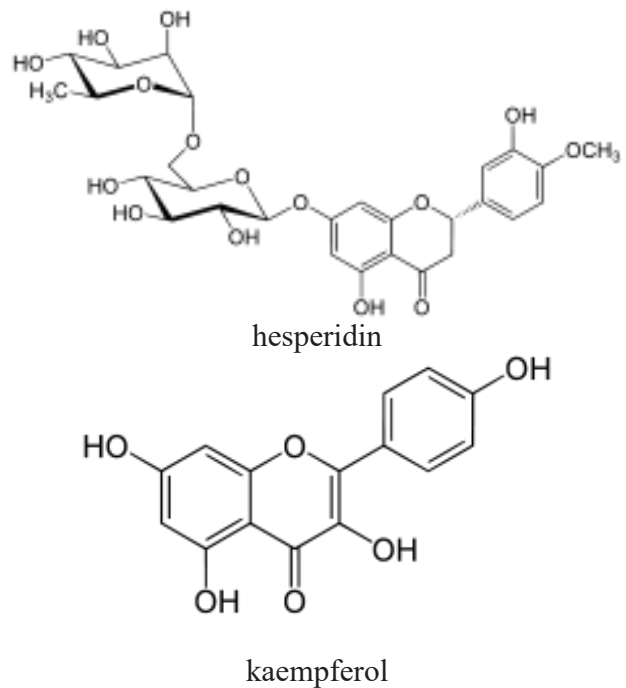

Fig 1. Chemical structure of studied flavonoids: chrysin, hesperidin, naringin and kaempferol.

Ryc. 1. Struktura chemiczna badanych flawonoidów: chryzyny, hesperydyny, narynginy i kemferolu.

The aim of the study is to assess the antiproliferative, cytotoxic and proapoptotic properties of the studied flavonoids, depending on their concentrations and respective activity time against hepatocellular carcinoma cells of the SK-Hep1 line in in vitro studies.

\section{MATERIAL AND METHODS}

\section{Material for research}

The following (Sigma-Aldrich, Poland) compounds were the research material (in brackets IUPAC names):

- hesperidin ((2S)-5-hydroxy-2-(3-hydroxy-4-methoxyphenyl)-7-[(2S,3R,4S,5S,6R)-3,4,5-trihydroxy6-[[(2R,3R,4R, 5R,6S )-3,4,5-trihydroxy-6methyloxan-2-yl]oxymethyl]oxan-2-yl]oxy-2,3dihydrochromen-4-one),

- naringin ((2S)-7-[(2S,3R,4S,5S,6R)-4,5-dihydroxy6-(hydroxymethyl)-3-[(2S,3R,4R,5R,6S)-3,4,5trihydroxy-6-methyloxan-2-yl] oxyoxan-2-yl] oxy-5-hydroxy-2-(4-hydroxyphenyl)-2,3dihydrochromen-4-one),

- $\quad$ chrysin (5,7-dihydroxy-2-phenylchromen-4-one),

- $\quad$ kaempferol (3,5,7,-trihydroxy-2-(4-hydroxyphenyl) chromen-4-one)

The properties of the flavonoids were tested in vitro on a hepatocellular carcinoma cell line obtained from the primary liver tumor SK-Hep1 from the ECACC (European Collection of Authenticated Cell Culture) collec- ticated Cell Culture) and then cultured according to the manufacturer's instructions.

The cells prepared in this way were subjected to further tests.

\section{Cytotoxicity assessment of chrysin, hesperidin and naringin with MTT assay}

The MTT test allows cell viability to be assessed by measuring the activity of energy transformations in mitochondria. This assay is based on the ability of the mitochondrial dehydrogenase enzyme to convert the soluble orange tetrazole salt to insoluble formazan, which is dark blue in color and dissolving the precipitate using DMSO. The dissolved crystals are subjected to colorimetric analysis at $570 \mathrm{~nm}$. In this way, the oxidative activity of the mitochondria of actively metabolic cells is determined, which is proportional to the amount of colored formazan [20].

\section{Evaluation of properties of chrysin, hesperidin and naringin using human Bcl-2 ELISA}

Human Bcl-2 ELISA is an enzyme-linked immunosorbent assay for the quantitative detection of Bcl-2. Bcl-2 initiates a new family of genes involved in the regulation of cell death and survival without affecting cell proliferation. Bcl-2 encoded by proto-oncogene is an intracellular membrane-bound protein that works to block programmed cell death. Decreasing Bcl-2 levels leads to cell death by apoptosis. In contrast, the overex- 


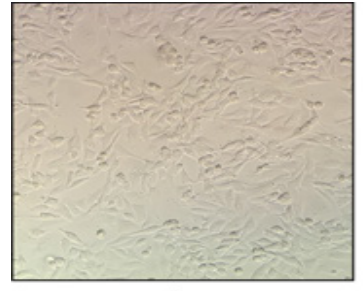

A

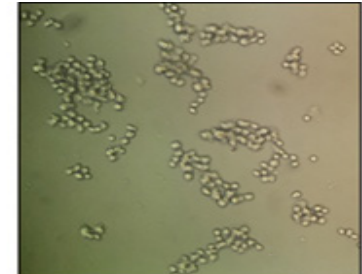

B

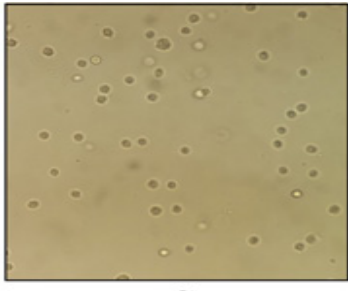

$\mathbf{C}$

Fig. 2. Trypsinization of SK Hep-1 cell lines observed by inverted microscope at 400x magnification. (A) Tumor cells occupying most of culture vessel. (B) Under influence of trypsin, cells detach from bottom and are suspended in solution. (C) Cells transferred to new vessels with appropriate confluence before adhesion to bottom of culture bottle [author's own modification].

Ryc. 2. Trypsynizacja linii komórkowych SK Hep-1 obserwowana pod mikroskopem odwróconym przy powiększeniu 400x. (A) Komórki nowotworowe zajmujące większość naczynia hodowlanego. (B) Pod wpływem trypsyny komórki odrywają się od dna i są zawieszane w roztworze. (C) Komórki przenoszone do nowych naczyń z odpowiednią konfluencją przed przyleganiem do dna butelki hodowlanej [modyfikacja własna].

pression of Bcl-2 protects cells from death, but is also able to cause the immortality of normal cells, which can cause the cancerous transformation of immortalized cells [21].

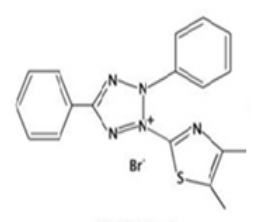

MTT

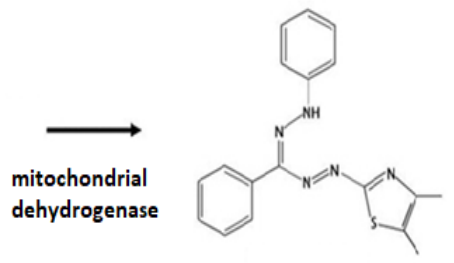

formazan
Fig. 3. Conversion of yellow MTT to purple formazan [20]. Ryc. 3. Konwersja żółtego MTT na fioletowy formazan [20].

\section{Determination of $\mathrm{IC}_{50}$ values for researched compounds}

The calculations were made using the ED 50 plus software version 1.0 computer program in the form of a spreadsheet for Microsoft Excel pharmacological analyses.

\section{Statistical analysis}

Statistical analysis of the results was performed using the Statistica 12 program (Statsoft Poland). The normality of the distribution of the studied parameters was checked by the Shapiro-Wilk test. Student's t-test was used to assess significance. Changes in relation to the control group at the significance level $\mathrm{p}<0.05$ were considered as statistically significant.

\section{RESULTS}

\section{Results of MTT assay}

Inhibition of the growth of SK Hep-1 liver cancer cells in vitro after application of the compounds: chrysin, hesperidin, naringin was assessed by the MTT dye viability test.
For chrysin, the viability of the SK-Hep1 liver cancer cells decreased with increasing studied substance concentrations. After 24 hours, its value was $94.79 \%$ for the concentration of $25 \mu \mathrm{mol} / \mathrm{L}$, while it was $69.37 \%$ for the concentration of $200 \mu \mathrm{mol} / \mathrm{L}$. After 48 hours of the experiment, cell viability continued to decline and was $94.28 \%$ at the lowest concentration, respectively, to $68.73 \%$ at $200 \mu \mathrm{mol} / \mathrm{L}$. On the last day (after $72 \mathrm{~h}$ ), cell viability was $83.77 \%$ for the concentration of 25 $\mu \mathrm{mol} / \mathrm{L}$ and $67.38 \%$ for the highest concentration. Hesperidin on the first day did not significantly reduce cell viability. A slight decrease in the viability of the SK-Hep1 cells was observed after 48 hours and it was $97.23 \%$ at $25 \mu \mathrm{mol} / \mathrm{L}, 94.82 \%$ at $50 \mu \mathrm{mol} / \mathrm{L} ; 92.54 \%$ for the concentration of $100 \mu \mathrm{mol} / \mathrm{L}$ and $88.79 \%$ for the concentration of $200 \mu \mathrm{mol} / \mathrm{L}$. After the third day, cell viability decreased from $96 \%$ at the lowest concentration used and reached $85.88 \%$ at $200 \mu \mathrm{mol} / \mathrm{L}$.

Naringin after 24 hours slightly reduced cell viability. A slightly larger decrease in the value was observed after 48 hours and it was $89.18 \%$ for the concentration of $25 \mu \mathrm{mol} / \mathrm{L}$, and $85.02 \%$ for the concentration of $200 \mu \mathrm{mol} / \mathrm{L}$. The next day of research did not affect the decrease in tumor cell viability. Only at the lowest concentration did it fall slightly to $84.3 \%$.

Kaempferol exhibited very interested results, namely after $24 \mathrm{~h}$ the viability decreased only to $94.90 \%$ at the highest dose. After $48 \mathrm{~h}$, the cytotoxicity effect was dose dependent in the range of 0 to $100 \mu \mathrm{mol} / \mathrm{L}$; however, the dose increasing from 50 to $100 \mu \mathrm{mol} / \mathrm{L}$ had only a slight impact on the cytotoxicity effect of kaempferol $(71.29 \%$ vs. $65.88 \%$ by 50 and $100 \mu \mathrm{mol} / \mathrm{L}$, respectively). Further dose increases (to $200 \mu \mathrm{mol} / \mathrm{L}$ ) had no significant impact on the measured viability change. Increasing the incubation time to $72 \mathrm{~h}$ did not exhibit any significant effect compared to those of $48 \mathrm{~h}$. $\mathrm{IC}_{50}$ is a commonly used measure for determining the amount of a given substance needed to inhibit a biological process under study. Using appropriate mathematical algorithms, the $\mathrm{IC}_{50}$ value was determined for the SK-Hep1 liver cancer cell line. This value determines the approximate concentration that inhibits the vital functions of $50 \%$ of the researched cells. 


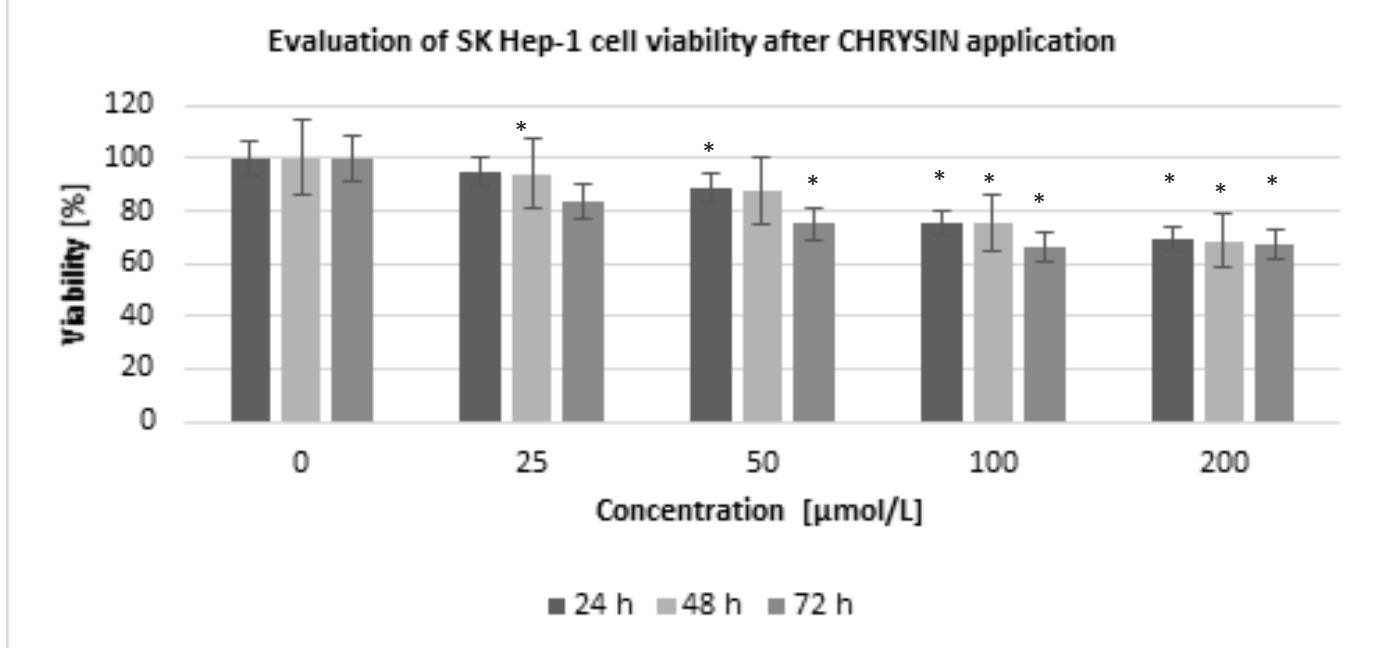

Fig. 4. Cytotoxic effect of chrysin at concentrations of $25,50,100$ and $200 \mu \mathrm{mol} / \mathrm{L}$ as a result of 24,48 and $72 \mathrm{~h}$ of cell incubation $\left({ }^{*}-p<0.05\right)$. Ryc. 4. Działanie cytotoksyczne chryzyny w stężeniach $25,50,100$ i 200 mol/L jako wynik 24,48 i 72 godzin inkubacji komórek.

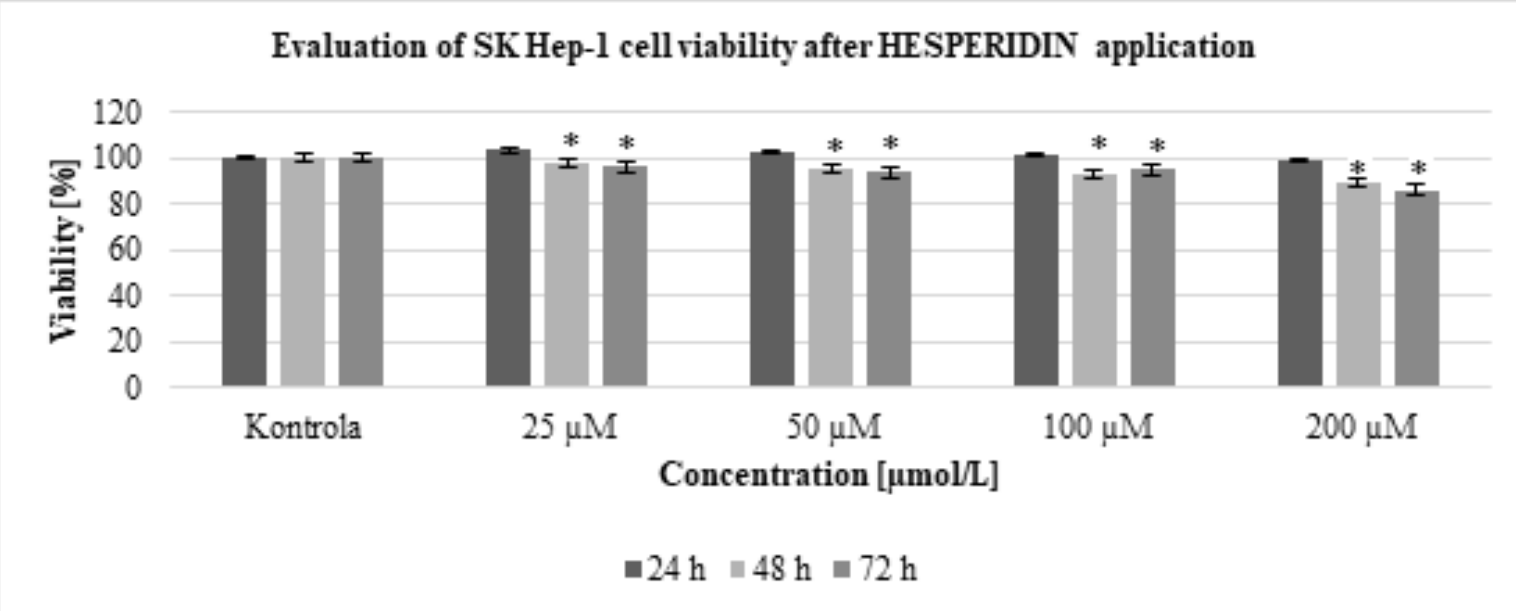

Fig. 5. Cytotoxic effect of hesperidin at concentrations of $25,50,100$ and $200 \mu \mathrm{mol} / \mathrm{L}$ as a result of 24,48 and $72 \mathrm{~h}$ of cell incubation $\left({ }^{*}-p<0.05\right)$. Ryc. 5. Cytotoksyczne działanie hesperydyny w stężeniach 25, 50, 100 i 200 mol//L jako wynik 24, 48 i 72 godzin inkubacji komórek.

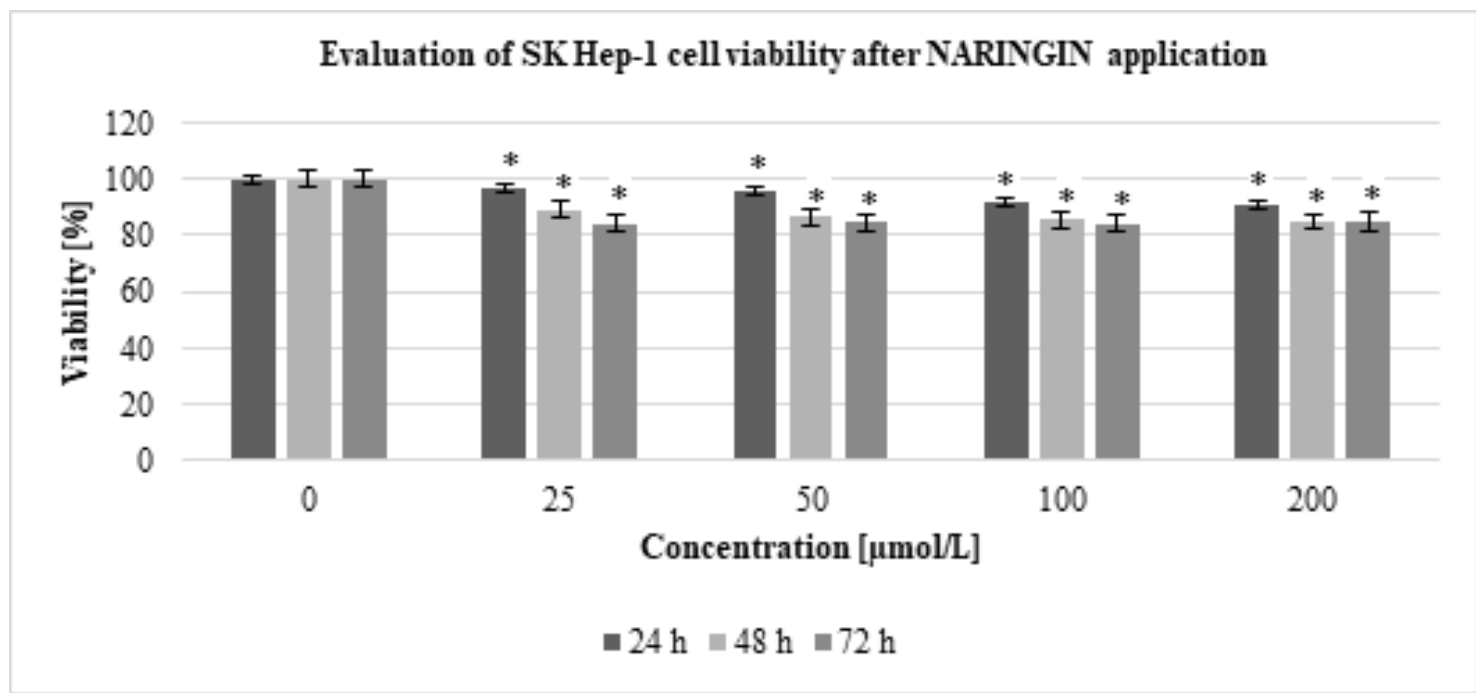

Fig. 6. Cytotoxic effect of naringin at concentrations of $25,50,100$ and $200 \mu \mathrm{mol} / \mathrm{L}$ as a result of 24,48 and $72 \mathrm{~h}$ of cell incubation $\left({ }^{*}-p<0.05\right)$. Ryc. 6. Działanie cytotoksyczne narynginy w stężeniach 25, 50, 100 i 200 mol/L jako wynik 24, 48 i 72 godzin inkubacji komórek. 


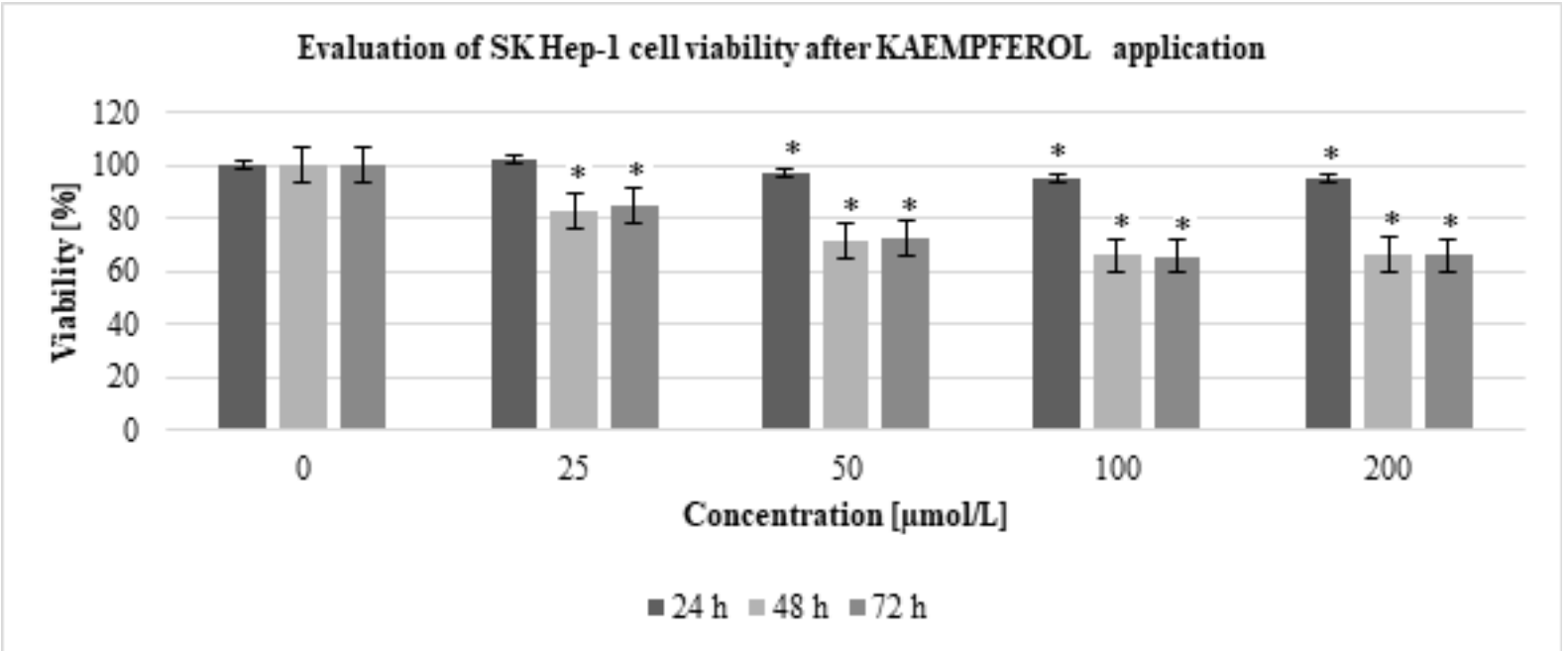

Fig. 7. Cytotoxic effect of kaempferol at concentrations of $25,50,100$ and $200 \mu \mathrm{mol} / \mathrm{L}$ as a result of 24,48 and $72 \mathrm{~h}$ of cell incubation $\left({ }^{*}-p<0.05\right)$. Ryc. 7. Działanie cytotoksyczne kemferolu w stężeniach od 25, 50, 100 i 200 mol/L jako wynik 24, 48 i 72 godzin inkubacji komórek.

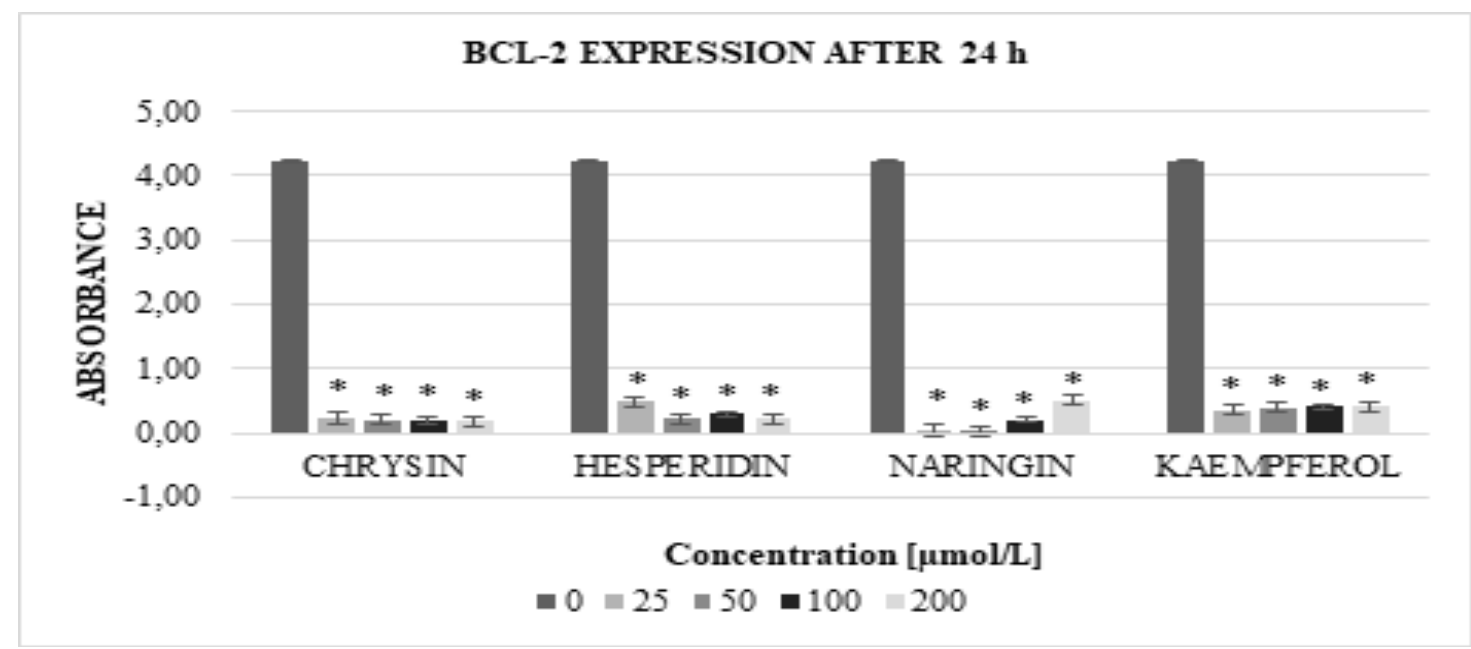

Fig. 8. Expression of Bcl-2 protein for individual compounds after 24 hours $\left({ }^{*}-p<0.05\right)$. Ryc. 8. Ekspresja białka Bcl-2 dla poszczególnych związków po 24 godzinach.

\section{BCL-2 EXPRESSION AFTER $48 \mathrm{~h}$}

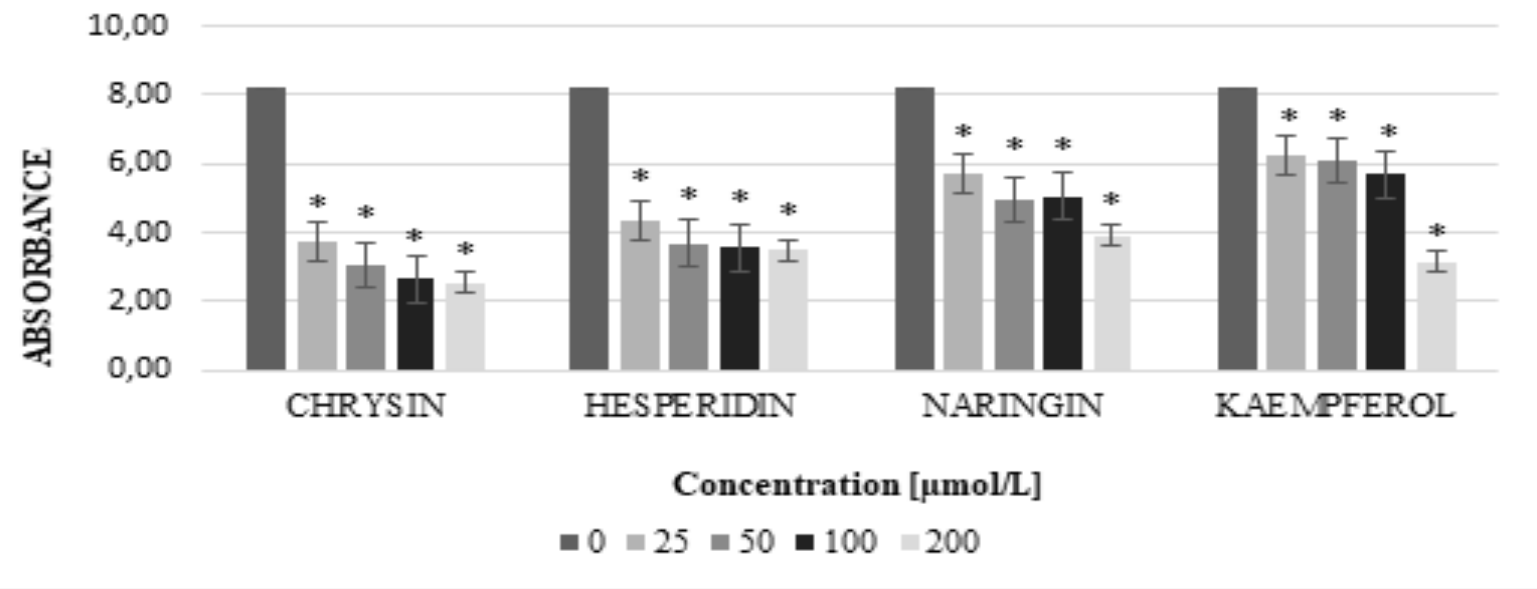

Fig. 9. Expression of Bcl-2 protein for individual compounds after 48 hours $\left({ }^{*}-p<0.05\right)$.

Ryc. 9. Ekspresja białka Bcl-2 dla poszczególnych związków po 48 godzinach. 


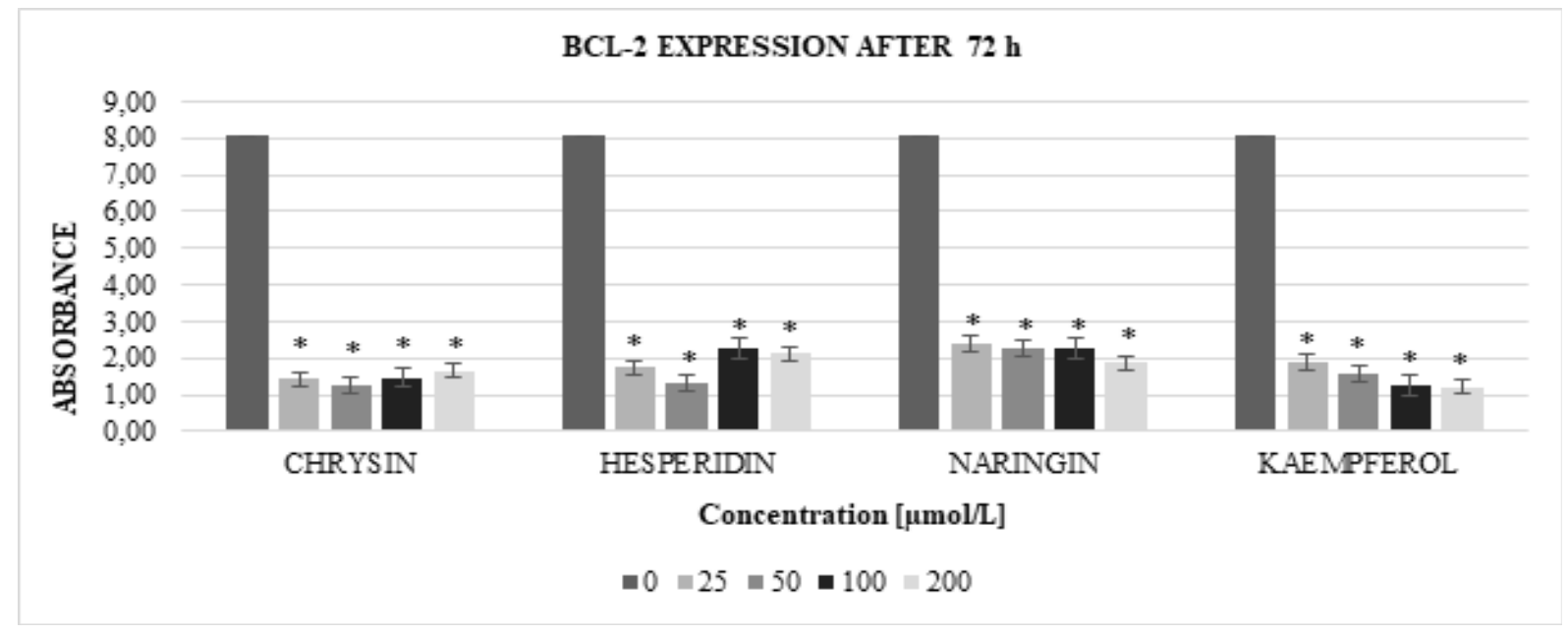

Fig. 10. Expression of $\mathrm{BCl}-2$ protein for individual compounds after 72 hours $\left({ }^{*}-p<0.05\right)$. Ryc. 10. Ekspresja białka Bcl-2 dla poszczególnych związków po 72 godzinach

\section{Human Bcl-2 ELISA results}

Determination of the concentration of proteins from the Bcl-2 family in the cell lysate of the SK Hep-1 liver cancer was performed by the ELISA method.

For chrysin, the level of $\mathrm{Bcl}-2$ protein expression decreased with increasing concentrations of the studied substance. After 24 hours, its expression was the highest for the concentration of $25 \mu \mathrm{mol} / \mathrm{L}$, while for the concentration of $200 \mu \mathrm{mol} / \mathrm{L}$ it had the lowest values. After 48 hours of the experiment, the level of Bcl-2 protein expression decreased as the concentration of researched substance increased. On the last day (after 72 hours), the level of expression of the studied protein changed statistically significantly so that it had the lowest value at the highest applied concentration.

$\mathrm{n}$ the case of hesperidin, after the first day we observed a decrease in the expression of the Bcl-2 family proteins in relation to the concentration of studied compound used. This tendency was also visible after another day. On the last day of the experiment, the expression of the studied parameter increased to a maximum at the concentration of $200 \mu \mathrm{mol} / \mathrm{L}$.

For naringin, in subsequent days of the experiment we observed a decrease in $\mathrm{Bcl}-2$ protein expression in relation to the highest concentration. However, for the concentration of $100 \mu \mathrm{mol} / \mathrm{L}$ there was a statistically insignificant increase in expression of the studied parameter. At the highest concentration, the expression of the tested proteins decreased significantly.

For kaempferol, as for chrysin, the level of Bcl-2 protein expression decreased with increasing concentrations of the test substance, for $48 \mathrm{~h}$ and $72 \mathrm{~h}$. After $24 \mathrm{~h}$ of the experiment, increasing the dose of kaempferol did not significantly impact Bcl-2 expression.

The last step was to compare the absorbance of the samples against the standards curve and determine the concentration of the Bcl-2 family proteins. For all the researched compounds, the highest level of Bcl-2 expression occurred after 48 hours and at the concentration of $25 \mu \mathrm{mol} / \mathrm{L}$.

Table I. Absorbance values, standard deviation (SD) and concentration of Bcl-2 family proteins at concentration of $25 \mu \mathrm{mol} / \mathrm{L}$ of studied compounds after 48 hours

Tabela I. Wartości absorbancji, odchylenie standardowe (SD) i stężenie białek z rodziny Bcl-2 przy stężeniu $25 \mu \mathrm{mol} / \mathrm{L}$ badanych zwiazków po 48 godzinach

\begin{tabular}{lccc}
\hline Compound & $\begin{array}{c}\text { Average } \\
\text { absorbance } \\
\text { value after } \\
\text { 48 hours }\end{array}$ & $\begin{array}{c}\text { Standard } \\
\text { deviation } \\
\text { value }\end{array}$ & $\begin{array}{c}\text { Bcl-2 family } \\
\text { protein } \\
\text { concentration } \\
\text { [ng/ml] }\end{array}$ \\
\hline Chrysin & 3.736 & 1.288 & 3.599 \\
Hesperidin & 4.323 & 2,029 & 4.169 \\
Naringin & 5.703 & 2.424 & 5.509 \\
Kaempferol & 6.235 & 1.277 & 6.017 \\
\hline
\end{tabular}

Table II. IC $\mathrm{C}_{50}$ values of test compounds in relation to SK Hep-1 liver cancer cell line

Tabela II. Wartości IC $\mathrm{C}_{50}$ badanych związków w stosunku do linii komórek raka wątroby SK Hep-1

\begin{tabular}{lccc}
\hline \multirow{3}{*}{ Studied compound } & \multicolumn{3}{c}{$\mathrm{IC}_{50}(\boldsymbol{\mu \mathrm { mol } / \mathrm { L } )}$} \\
\cline { 2 - 4 } & $\mathbf{2 4 \mathrm { h }}$ & $\mathbf{4 8 \mathrm { h }}$ & $\mathbf{7 2} \mathrm{h}$ \\
\hline Chrysin & 320.19 & 316.67 & 378.66 \\
Hesperidin & $>1000$ & $>1000$ & 866.97 \\
Naringin & $>1000$ & $>1000$ & $>1000$ \\
Kaempferol & $>1000$ & 373.35 & 345.91 \\
\hline
\end{tabular}

\section{Statistical analysis}

Statistical analysis of the results was carried out using Statistica 12 from Statsoft Poland. In addition, $\mathrm{IC}_{50}$ values were determined for the researched compounds. The calculations were made using the ED 50 plus software version 1.0 computer program in the form of a spreadsheet for Microsoft Excel pharmacological 
analyses. The normality of the distribution of the studied parameters was verified by the Shapiro-Wilk test. Student's t-test was used to assess significance. Changes at the significance level $\mathrm{p}<0.05$ were considered statistically significant.

\section{DISCUSSION}

According to statistical data, every second patient with cancer uses alternative and unconventional cancer treatments. Many methods of natural medicine are rooted in centuries of tradition. Compounds of plant origin have been used in the treatment of infections, inflammations, as analgesics and limiting the undesirable effects of conventional treatment. Phytotherapeutics undergo clinical trials to determine their applicability in chemotherapy, and many commonly used pharmaceuticals have been synthesized by the similarity to their plant counterparts [22].

Compounds of natural origin are also used in the chemoprevention of tumors. Chemoprevention is gaining interest as a cheap, easy to apply and widely available way of preventing cancer. Epidemiological studies have unequivocally shown that the consumption of large amounts of fruit and vegetables reduces the likelihood of cancer [23].

The risk of developing liver cancer is mainly influenced by external factors. In $80 \%$ of cases, poor diet, excessive alcohol consumption and smoking contributed to cancer. The risk factors for hepatocellular carcinoma also include the long-term use of contraceptives, exposure to aflatoxins, as well as hepatitis B and C infection. Liver cancer often develops in patients suffering from metabolic diseases with primary biliary cirrhosis or fatty liver [24].

Primary liver tumors are 30 times less common than metastatic lesions. The most common primary hepatic malignancies include hepatocyte carcinoma (hepatocellular carcinoma (HCC) and cholangiocarcinoma (CCC) [25].

Primary liver changes are diagnosed late. Hepatocellular carcinoma does not give specific symptoms, or they are long ignored by patients. At the initial stage of the disease there is weakness, easy fatigue, a low-grade fever, loss of appetite and painful muscle cramps (especially at night). Only in the advanced condition does the patient develop jaundice, weight loss, ascites, or encephalopathy [26].

There are no screening tests that could detect a change in the early stages of the disease. Most often, a liver tumor is diagnosed accidentally by ultrasound. Unfortunately, treatment is limited in patients with a late diagnosis. Surgery is only possible in a small percentage of cases. In some patients ablation techniques involving injecting chemicals into the absolute tumor or irradiating the tumor with energy from near-radio frequency (RFA) are used. Advanced forms of the disease are only eligible for palliative treatment $[27,28]$.
Phytotherapy in some countries has become part of academic medicine and is widely used in oncological therapy. Plant-derived compounds have also been used to treat liver cancer.

Flavonoids (baicalein, casticin, apigenin), isoflavones (tectorigenin) and flavonols (galangin, quercetin) increase the susceptibility of hepatocellular carcinoma cells to apoptosis by interfering with the intracellular apoptotic pathway and affecting cell proliferative potential $[29,30,31]$.

Apoptosis initiated by mitochondria is induced in the hepatocellular carcinoma cells of the HepG2 line by tectorigenin obtained from the iris rhizome [32].

Our research showed that the viability of SK-Hep1 liver cancer cells slightly decreased with an increase in chrysin concentration and with the passage of time of its action on cancer cells and was $94.79 \%$ for $25 \mu \mathrm{mol} / \mathrm{L}$ and $69.37 \%$ for $200 \mu \mathrm{mol} / \mathrm{L}$, respectively after $24 \mathrm{~h}$, while after $72 \mathrm{~h}$ hours, cell viability decreased to $83.77 \%$ for $25 \mu \mathrm{mol} / \mathrm{L}$ and $67.38 \%$ for $200 \mu \mathrm{mol} / \mathrm{L}$.

Deng X. et al. [33] investigated the mechanisms of the tumorigenic effect of chrysin on HepG2 cells by fluorescence staining, flow cytometry and immunoblotting. The results showed that the inhibitory activity of chrysin was much stronger than quercetin or naringenin in 48 hours of research.

Our research indicates a stronger cytotoxic effect of hesperidin compared to naringin. After 72 hours, the $\mathrm{IC}_{50}$ for hesperidin was $866.97 \mu \mathrm{mol} / \mathrm{L}$ and for naringin $>1000 \mu \mathrm{mol} / \mathrm{L}$.

Banjerdpongchai R. et al. [34] obtained very similar effects. They conducted studies aimed at assessing the cytotoxic activity and apoptosis of selected flavonoids in relation to HepG2 cells. The authors demonstrated the anticancer activity of hesperidin and naringin. The cytotoxic effect of these compounds was determined by $\mathrm{IC}_{50}$ determination and was dose dependent. The sensitivity of human HepG2 cells was as follows: hesperidin $>$ naringin.

In the case of the next compound, kaempferol, after the first day of administration of this compound, cell viability decreased slightly. Nonetheless, after $48 \mathrm{~h}$, the viability of liver cancer cells significantly decreased and reached $82.78 \%$ for the concentration of $25 \mu \mathrm{mol} / \mathrm{L}$ and $66.04 \%$ for the concentration of $200 \mu \mathrm{mol} / \mathrm{L}$. The next day did not affect the decrease in cell viability.

Xiaofeng Shi et al. [35] observed in their studies that kaempferol was more potent compared to another flavonoid - quercetin. The authors examined the effect of the compounds on HeLa cervical cancer cell lines, stomach cancer MKN28 cells, glioblastoma SHG-44 cells and A549 lung cancer, and HepG2 liver cancer. The MTT test used showed that the studied flavonoids inhibited the growth of HepG2 cells in a dose-dependent manner. Studies have shown that even at lower doses, flavonoids effectively inhibited HepG2 cell proliferation and also our research confirmed this thesis. Comparison of the $\mathrm{IC}_{50}$ values indicated that HepG2 cells may be more 
sensitive to flavonoid treatment compared to the cells of the other researched cancers.

\section{CONCLUSIONS}

The obtained test results indicate the cytotoxic activity of the researched compounds in relation to SK HEP-2 liver cancer lines depending on the time of exposure to the studied compound and the dose of flavonoid used. Significant cytotoxic effects of chrysin were observed at concentrations of $100 \mu \mathrm{mol} / \mathrm{L}$ and $200 \mu \mathrm{mol} / \mathrm{L}$ after 48 hours. The next day did not bring significant differences in the activity of the researched compound.

In the case of hesperidin, the decrease in cell viability occurred after $48 \mathrm{~h}$ and lasted up to $72 \mathrm{~h}$ and was most pronounced when the flavonoid was used at the following concentrations: $50 \mu \mathrm{mol} / \mathrm{L}, 100 \mu \mathrm{mol} / \mathrm{L}$ and $200 \mu \mathrm{mol} / \mathrm{L}$. The largest decrease in cell viability was observed after the use of kaempferol, which was visible from the lowest concentration after 48 hours and lasted up to 72 hours. Cell viability decreased slightly after naringin treatment, which, similar to kaempferol, was already visible at the concentration of $25 \mu \mathrm{mol} / \mathrm{L}$ after 48 hours and decreased as the concentration of the administered substance increased and with time.

\section{RESEARCH FINANCING}

This research was supported by Medical University of Silesia in Katowice, project no. KNW-1-042/N/6/O.

\section{Author's contribution}

Study design - T. Skalny, A. Kleczka

Data collection - A. Owczarzy

Data interpretation - R. Kubina, M. Wyszyńska, A. Kabała-Dzik

Statistical analysis - R. Kubina, A. Kleczka

Manuscript preparation - A. Kleczka, A. Kabała-Dzik

Literature research - A. Owczarzy, M. Wyszyńska, T. Skalny

\section{REFERENCE}

1. Data of WHO z http://www.who.int/mediacentre/factsheets/fs297/en/ [dostęp: 02.10.2017].

2. Srivatanakul P., Sriplung H., Deerasamee S. Epidemiology of liver cancer: an overview. Asian Pac. J. Cancer Prev. 2004; 5(2): 118-125.

3. Wojciechowska U., Olasek P., Czauderna K., Didkowska J. Nowotwory złośliwe w Polsce w 2014 roku. Krajowy Rejestr Nowotworów Zakład Epidemiologii i Prewencji Nowotworów. Warszawa 2016. http://onkologia.org.pl/ raporty/ [dostęp: 02.10.2017]

4. McGlynn K., London T. The Global Epidemiology of Hepatocellular Carcinoma, Present and Future. Clin. Liver Dis. 2011; 15(2): 223-243, vii-x, doi: 10.1016/j.cld.2011.03.006

5. Peck-Radosavljevic M. Drug therapy for advanced-stage liver cancer. Liver Cancer 2014; 3(2): 125-131, doi: 10.1159/000343868.

6. Rajesh E., Sankari L., Malathi L., Krupaa J. Naturally occurring products in cancer therapy. J. Pharm. Bioallied. Sci. 2015; 7(Suppl 1): S181-S183, doi: 10.4103/0975-7406.155895.

7. Chahar M., Sharma N., Dobhal M., Joshi Y. Flavonoids: A versatile source of anticancer drugs. Pharmacogn. Rev. 2011; 5(9): 1-12, doi: 10.4103/0973 7847.79093.

8. Das A., Banik N.L., Ray S.K. Flavonoids activated caspases for apoptosis in human glioblastoma T98G and U87MG cells but not in human normal astrocytes. Cancer 2010; 116 (1): 164-176, doi: 10.1002/cncr.24699.

9. Vukovic N.L., Obradovic A.D., Vukic M.D., Jovanovic D., Djurdjevic P.M Cytotoxic, proapoptotic and antioxidative potential of flavonoids isolated from propolis against colon (HCT-116) and breast (MDA-MB-231) cancer cell lines. Food Res. Int. 2018; 106: 71-80, doi: 10.1016/j.foodres.2017.12.056.

10. Lirdprapamongkol K., Sakurai H., Abdelhamed S., Yokoyama S., Maruyama T., Athikomkulchai S., Viriyaroj A., Awale S., Yagita H., Ruchirawat S. Svasti J., Saiki I. A flavonoid chrysin suppresses hypoxic survival and metastatic growth of mouse breast cancer cells. Oncol. Rep. 2013; 30(5): 2357-2364, doi: 10.3892/or.2013.2667.

11. Kasala E.R., Bodduluru L.N., Madana R.M., Gogoi R., Barua C.C. Chemopreventive and therapeutic potential of chrysin in cancer: mechanistic perspectives. Toxicol. Lett. 2015 4; 233(2): 214-225, doi: 10.1016/j.toxlet.2015.01.008 12. Lee C.J., Wilson L., Jordan M.A., Nguyen V., Tang J., Smiyun G. Hesperidin suppressed proliferations of both human breast cancer and androgendependent prostate cancer cells. Phytother. Res. 2010; 24; Suppl 1: 15-19, doi: $10.1002 /$ ptr. 2856

13. Ahmadi A., Shadboorestan A. Oxidative stress and cancer; the role of hesperid13. in, a citrus natural bioflavonoid, as a cancer chemoprotective agent Nutr. Cancer. 2016; 68(1): 29-39, doi: 10.1080/01635581.2015.1078822.

14. Khoo B.Y., Chua S.L., Balaram P. Apoptotic Effects of Chrysin in Human Cancer Cell Lines. Int. J. Mol. Sci. 2010; 11(5): 2188-2199, doi: 10.3390/ ijms11052188.

15. Zhao J., Li Y., Gao J., De Y. Hesperidin inhibits ovarian cancer cell viability through endoplasmic reticulum stress signaling pathways. Oncol. Lett. 2017; 14. 5569-5574, doi: 10.3892/ol.2017.6873.

16. Alam A.M., Subhan N.M., Rahman M., Uddin S.J., Reza H.M., Sarker S.D.. Effect of Citrus Flavonoids, Naringin and Naringenin, on Metabolic Syndrome and Their Mechanisms of Action. Adv. Nutr. 2014; 5(4): 404-417, doi: 10.3945/an.113.005603.

17. Chen A.Y., Chen Y.C. A review of the dietary flavonoid, kaempferol on human health and cancer chemoprevention. Food Chem. 2013; 138(4): 2099 -2107, doi: 10.1016/j.foodchem.2012.11.139.

18. Geybels M.S., Verhage B.A., Arts I.C., van Schooten F.J., Goldbohm R.A., van den Brandt P.A. Dietary flavonoid intake, black tea consumption, and risk of overall and advanced stage prostate cancer. Am. J. Epidemiol. 2013; 177(12): 1388-1398, doi: 10.1093/aje/kws419.

19. Anand P., Kunnumakkara A.B., Sundaram C., Harikumar K.B., Tharakan S.T., Lai O.S., Sung B., Aggarwal B.B. Cancer is a preventable disease that requires major lifestyle changes. Pharm. Res. 2008; 25(9): 2097-2116, doi: 10.1007/s11095-008-9661-9.

20. Biotum. MTT Cell Viability Assay Kit 2014; https://biotium.com/wp-content/uploads/2013/07/PI-30006.pdf [dostęp: 10.05.2018]

21. BioVendor. Human Bcl2 ELISA 2017; https://www.biovendor.com/ file/5441/PDS_B29_HBcl2E_ENG.00.A.pdf?version=201704302053 [dostęp: 15.05.2018]

22. Riboli E., Norat T. Epidemiological evidence of the protective effect of fruit and vegetables on cancer risk. Am. J. Clin. Nutr. 2003; 78(3 Suppl): 559S-569S, doi: 10.1093/ajen/78.3.559S.

23. Epping-Jordan J.E., Galea G., Tukuitonga C., Beaglehole R. Preventing chronic diseases: Taking stepwise action. Lancet 2005; 366(9497): 1667-1671, doi: 10.1016/S0140-6736(05)67342-4.

24. Blumberg B.S. Primary and secondary prevention of liver cancer caused by HBV. Front Biosci. (Schol Ed). 2010; 2: 756-763, doi: 10.2741/s98.

25. Volk M.L., Marrero J.A. Early detection of liver cancer: diagnosis and management. Curr. Gastroenterol. Rep. 2008; 10(1): 60-66, doi: 10.1007/s11894008-0010-2.

26. Bialecki E.S., Di Bisceglie A.M. Diagnosis of hepatocellular carcinoma. HPB (Oxford) 2005; 7(1): 26-34, doi: 10.1080/13651820410024049.

27. Kudo M. Surveillance, diagnosis, treatment, and outcome of liver cancer in Japan. Liver Cancer. 2015; 4(1): 39-50, doi: 10.1159/000367727. 
28. Liang R.R., Zhang S., Qi J.A., Wang Z.D., Li J., Liu P.J., Huang C., Le X.F., Yang J., Li Z.F. Preferential inhibition of hepatocellular carcinoma by the flavonoid baicalein through blocking MEK-ERK signaling. Int. J. Oncol. 2012; 41: 969-978, doi: 10.3892/ijo.2012.1510.

29. Kim B.R., Jeon Y.K., Nam M.J. A mechanism of apigenin-induced apoptosis is potentially related to anti-angiogenesis and anti-migration in human hepatocellular carcinoma cells. Food Chem. Toxicol. 2011; 49(7): 1626-1632, doi: 10.1016/j.fct.2011.04.015

30. Zhang H.T., Luo H., Wu J., Lan L.B., Fan D.H., Zhu K.D., Chen X.Y., Wen M., Liu H.M. Galangin induces apoptosis of hepatocellular carcinoma cells via the mitochondrial pathway. World J. Gastroenterol. 2010; 16(27): 3377-3384, doi: 10.3748/wjg.v16.i27.3377.

31. Fang R., Houghton P.J., Hylands P.J. Cytotoxic effects of compounds from Iris tectorum on human cancer cell lines. J. Ethnopharmacol. 2008; 118(2): 257-263, doi: 10.1016/j.jep.2008.04.006
32. Kim I., Xu W., Reed J.C. Cell death and endoplasmic reticulum stress: Disease relevance and therapeutic opportunities. Nat. Rev. Drug Discov. 2008; 7(12): 1013-1030, doi: $10.1038 /$ nrd2755

33. Deng X., Zhao X., Lan Z., Jiang J., Yin W., Chen L. Anti-tumor effects of flavonoids from the ethnic medicine Docynia delavayi (Franch.) Schneid. and its possible mechanism. J. Med. Food. 2014; 17(7): 787-794, doi: 10.1089/ jmf.2013.2886.

34. Banjerdpongchai R., Wudtiwai B., Khaw-On P., Rachakhom W., Duangnil N., Kongtawelert P. Hesperidin from Citrus seed induces human hepatocellular carcinoma HepG2 cell apoptosis via both mitochondrial and death receptor pathways. Tumour Biol. 2016; 37(1): 227-237, doi: 10.1007/s13277-0153774-7.

35. Shi X., Liu D., Zhang J., Hu P., Shen W., Fan B., Ma Q., Wang X. Extraction and purification of total flavonoids from pine needles of Cedrus deodara contribute to anti-tumor in vitro. BMC Complement Altern. Med. 2016; 16: 245, doi: 10.1186/s12906-016-1249-z 